\title{
Knowledge and attitude towards hematopoietic stem cell transplantation among medical students at Jazan University, Saudi Arabia
}

Ahmad A. Hazzazi, Medical student, Mohssen H. Ageeli, Medical student, Abdulaziz M. Alfaqih, Medical student, Amnah K. Zakri, Medical student, Erwa E. Elmakki, MD.

\begin{abstract}
الأهداف : تحديد معرفة ومواقف طلاب الطب تجاه زراعة الحلايا

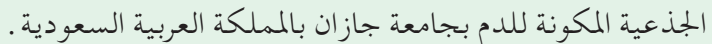

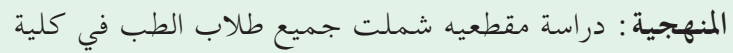

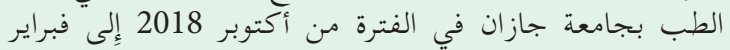

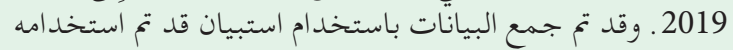

في دراسة سابقه في مدرسة مايو الطبية مينيسوتا، باستخام امريكا.

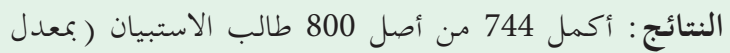

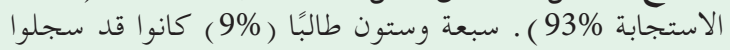

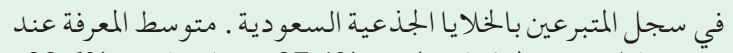

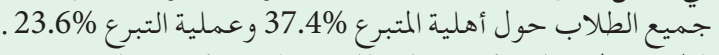

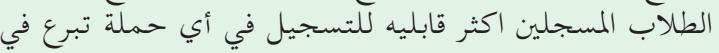

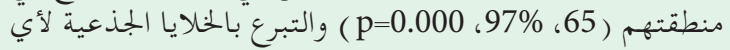

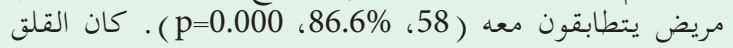
أعلى بالنسبة للآثار الجانبية طويلة الأجل ( 48\% ) .

الخلاصة : بشكل عام، فِإن غالبية الطلاب يفتقرون إِلى المعاب المعرفة

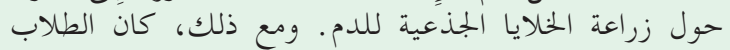

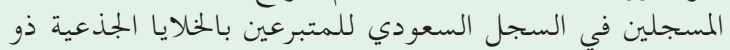

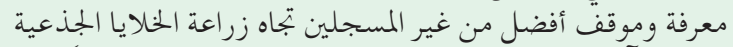

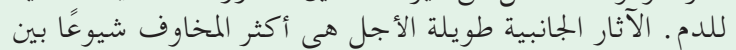

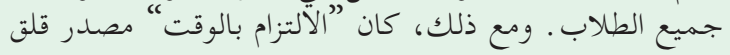

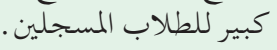

Objectives: To identify the knowledge and attitudes of medical students at Jazan University towards hematopoietic stem cell transplantation (HSCT).

Methods: This cross-sectional study involved all medical students at the Faculty of Medicine, Jazan University, Jazan, Saudi Arabia, between October 2018 and February 2019. Data were collected using a questionnaire that has been used in a previous study conducted at Mayo Medical School, Minnesota, USA.
Results: Out of 800 students, 744 completed the questionnaire (the response rate was $93 \%$ ). Sixty-seven students (9\%) were already registered in the Saudi stem cell donor registry (SSCDR). The participants' knowledge on donor eligibility was $37.4 \%$ and the donation process was $23.6 \%$. Registered students were more likely to join the registry if there was a drive in their area $(\mathrm{n}=65[97 \%], p=0.000)$, and more likely to donate stem cells to any matched patient $(\mathrm{n}=58$ [86.6\%], $p=0.000)$. The main concern of the participants was the long-term side effects (48\%).

Conclusion: Most students lack the knowledge on HSCT. However, the students who registered in SSCDR had better knowledge and attitudes towards HSCT than the unregistered. Long-term side effects of HSCT were the most common concern of the participants. However, time commitment was the major concern of the registered students.

Saudi Med J 2019; Vol. 40 (10): 1045-1051

doi:10.15537/smj.2019.10.24294

From the Department of Internal Medicine, Faculty of Medicine, Jazan University, Jazan, Kingdom of Saudi Arabia.

Received 4th June 2019. Accepted 8th September 2019.

Address correspondence and reprint request to: Dr. Ahmad A. Hazzazi, Department of Internal Medicine, Faculty of Medicine, Jazan University, Jazan, Kingdom of Saudi Arabia. E-mail:Ahmad.Amdamr@gmail.com

ORCID ID: orcid.org/0000-0001-5148-6184 
$\mathrm{H}$ ematopoietic stem cell transplantation (HSCT) is a lifesaving modality of treatment for many conditions. ${ }^{1}$ Hematopoietic stem cell transplantation is used as curative therapy for various hematological disorders such as sickle cell anemia, thalassemia, lymphomas, leukemias, Fanconi anemia, aplastic anemia, and severe combined immunodeficiency. ${ }^{2}$ There are 2 main procedures used for HSCT. The 2 procedures are bone marrow transplantation (BMT) and peripheral blood stem cell transplantation (PBSCT). Recently, PBSCT replaces BMT as a source for stem cells in around 3 quarters of cases. ${ }^{3}$ The hematopoietic stem cells have the ability to differentiate and produce mature red blood cells (RBCs) and immune cells as it serve as a lifelong source of blood cells. ${ }^{2}$ Hematopoietic stem cell transplantation carries many possible complications including infection, hemorrhage, graft failure, acute or chronic graft versus host disease, and major organ failure. Mortality related to HSCT were influenced by many factors such as age, gender, health status, disease stage, and the process of transplantation. ${ }^{4}$ Studies have shown that the donor's age had a significant effect on the success of the transplant as the donation from the youngers was associated with lower complications. ${ }^{5}$ The chance of finding a well-matched donor inside the family ranges from $25-30 \%$. Fully matched human leukocyte antigen (HLA) sibling is considered the best donor. For other patients who have not matched family member, the transplantation from an unrelated volunteer donor can be a possible alternative. ${ }^{6}$ In Turkey, Balci et al, ${ }^{7}$ found that $74 \%$ of patients found matching sibling, $10 \%$ were matching with father and $12 \%$ were matching with mother. High consanguinity was playing an important role in increasing the availability of finding matched family member. However, finding a matched donor in the family is affected by the family size. ${ }^{7}$ The association between consanguinity and finding matched donor is considered a point of benefit for Saudi population; as half of Saudi marriages were consanguineous. ${ }^{8-10}$ The high consanguinity rates in Kingdom of Saudi Arabia (KSA) account for the high prevalence of genetic diseases such as sickle cell disease. Approximately 61000 of sickle cell patients live in the KSA. Nearly one-fifth of these patients might require HSCT if they experience frequent severe pain, recurrent acute chest syndrome or stroke. The restricted number of transplant centers in KSA cannot meet this

Disclosure. Authors have no conflict of interests, and the work was not supported or funded by any drug company. huge demand at the present time. ${ }^{11}$ The individuals' knowledge and attitudes toward organ donation were found to be significantly associated with their intention to being registered as organ donors. On the other hand, medical students were considered important sources of correct information or misinformation to the general population and they can influence the general population attitudes regarding organ donation, therefore studies about medical students' knowledge and attitudes are of great importance. ${ }^{1}$ Medical students have the basic knowledge about transplantation but lack the deep knowledge and require further teaching about this subject. ${ }^{12}$ Because HSCT was recently applied in KSA, it required effective cooperation from the Saudi population to enhance its success by more registrations and donations. However, this cooperation requires more knowledge among the population regarding HSCT. This cooperation can be increased by medical students who play an important role in the spread of accurate knowledge and the confrontation of misconceptions to the general population regarding various topics including HSCT. For these reasons, the main objective of this study was to determine medical students' attitudes towards HSCT and to explore their current knowledge status on HSCT.

Methods. This cross-sectional study was conducted in the faculty of medicine of Jazan University, Jazan, KSA between October 2018 and February 2019. Data were collected using a questionnaire that has been used in a previous study which was conducted in Mayo Medical School, Minnesota, USA. ${ }^{1}$ Minor modifications were carried out in the questionnaire to make it more suitable for use by medical students at Jazan University, Jazan, KSA. The modified version of the questionnaire was revised by an associate professor in the Medicine Department, Faculty of Medicine for its clarity. Then, we performed a pilot study that involved 50 students who were selected from different preclinical and clinical years. Reliability of the modified version of the questionnaire then tested and Cronbach's alpha value for knowledge questions was 0.70 and for attitude questions was 0.83 . The period of study in the Faculty of Medicine, Jazan University is 6 years divided into 2 parts: the pre-clinical (the first 3 years) and the clinical part (the late 3 years). Approximately 800 male and female medical students are studying at the Faculty of Medicine. A hard copy of the questionnaire in English language was distributed to all medical students in both preclinical and clinical years during the period from October 2018 to February 2019. All medical students were involved in the study and the questionnaire was 
distributed to all of them with the help of classes' leaders in each year with the aim to get high response rate and to minimize the number of returned questionnaires with many missing values. The questionnaire was divided into 5 sections; first, sociodemographic data including age, gender, academic year, grade point average (GPA) and marital status. Second section included questions about the experience in donation such as previous stem cell or bone marrow donation and previous blood or blood products donation. Third section was constructed for the assessment of knowledge about donor eligibility (DE) and the donation process (DP). Three questions for knowledge about DE and 3 for DP with answers true, false or don't know. Fourth section was set to assess medical students' attitudes toward donating stem cells and fifth section was set to assess their concerns regarding the donation process. Five-Likert scale questions ranging from strongly agree to strongly disagree were used for assessment of students' attitude and concerns. Written consent was taken from all participants. Ethical approval of the present study was obtained from Jazan Institutional Review Board (NO. 1843).

Statistical analysis. Before data entry, data were checked and verified manually for any mistakes. Questionnaires with many missing values were excluded and were not included in the analysis. The Statistical Package for Social Sciences, version 25 (IBM Corp., Armonk, NY, USA) was used for data analysis. Categorical variables were presented in numbers and percentages. For knowledge questions, we used "true", "false/I don't know questions", then the average correct answers were measured. Regarding attitude and concern questions, "strongly agree" and "agree" were merged together to be "agree" and the same was applied to the answers with "strongly disagree" and "disagree". Comparison between categorical variables was performed using the Chi-squared test. Any $p<0.05$ indicated statistical significance. Multivariate binary logistic regression was performed to identify the factors can predict being a member of Saudi stem cell donor registry (SSCDR).

Results. Among 800 medical students, 744 students completed the questionnaire (response rate, 93\%). The majority of participants were female $(n=422,56.7 \%)$. About two-thirds of the participants were within the ages of $18-22$ years $(n=461,61.96 \%) ; 67$ students $(9 \%)$ were already registered in SSCDR. Forty-nine percent $(n=363)$ of students were in the preclinical years and $51 \%(n=381)$ were in the clinical years. Grade point average of the majority of students ranged between 2.00-4.5 ( $\mathrm{n}=529 \quad[71.1 \%])$. Approximately 90\% $(n=674)$ of the participants were singles. Students between 23-25 years of age were significantly more likely to be registered ( $\mathrm{n}=35$ [52.2\%], $p=0.018)$. Students studying in the clinical years were more likely to be registered $(p=0.00)$ especially students in the 5 th year $(p=0.00)$. Middle level GPA 2.00-4.5 was found to be significantly associated with being on the registry $(p=0.029)$ (Table 1).

Marital status had no significant association with registry status $(p=0.594)$. Students who were already registered in SSCDR were more likely to have a history of donating bone marrow $(\mathrm{n}=6[9 \%], p=0.00)$, donating peripheral blood stem cells $(\mathrm{n}=12$ [18\%], $p=0.00)$, donating stem cells to a family member $(\mathrm{n}=3,4.5 \%$; $p=0.005)$, donating stem cells to an unrelated recipient $(\mathrm{n}=6$ [9\%], $p=0.000)$, donating blood or blood products $(\mathrm{n}=24$ [36\%], $p=0.001)$ (Table 2). Multivariable binary logistic regression showed that being a student in the 5th year $(\mathrm{OR}=5.90,95 \% \mathrm{CI}: 1.58-22.03, p=0.008)$, previous history of blood donation $(\mathrm{OR}=2.19,95 \% \mathrm{CI}$ : $1.10-4.37, p=0.26)$, bone marrow donation $(\mathrm{OR}=7.13$, 95\% CI: $1.26-40.42, p=0.26)$ and peripheral blood stem cell donation $(\mathrm{OR}=9.09,95 \% \mathrm{CI}$ : 2.66-31.03, $p=0.000)$ is associated with more likelihood to be a member of SSCDR. However, GPA $(p=0.395)$ and

Table 1 - Participant's sociodemographic data (N=744).

\begin{tabular}{|c|c|c|c|}
\hline Variable & On registry & Not on registry & $P$-value \\
\hline Total & $67(9.0)$ & $677(91.0)$ & \\
\hline \multicolumn{4}{|l|}{ Age } \\
\hline $18-22$ years & $31(46.3)$ & $430(63.5)$ & \multirow{3}{*}{$0.018^{*}$} \\
\hline $23-25$ year & $35(52.2)$ & $236(34.9)$ & \\
\hline$>25$ year & $1(1.5)$ & 11 (1.6) & \\
\hline \multicolumn{4}{|l|}{ Gender } \\
\hline Male & $26(38.8)$ & $296(43.7)$ & \multirow{2}{*}{0.438} \\
\hline Female & $41(61.2)$ & $381(56.3)$ & \\
\hline \multicolumn{4}{|l|}{ Academic year } \\
\hline 2nd year & $5(7.5)$ & $177(24.5)$ & \multirow{5}{*}{$0.000^{*}$} \\
\hline 3rd year & $12(17.9)$ & $169(24.3)$ & \\
\hline 4th year & $14(20.9)$ & $135(20.0)$ & \\
\hline 5 th year & $24(35.8)$ & $101(16.8)$ & \\
\hline 6th year & $12(17.9)$ & $95(14.4)$ & \\
\hline \multicolumn{4}{|c|}{ Education level } \\
\hline Pre-clinical & $17(25.4)$ & $346(51.1)$ & \multirow{2}{*}{$0.000^{*}$} \\
\hline Clinical & $50(74.6)$ & $331(48.9)$ & \\
\hline \multicolumn{4}{|c|}{ Grade point average (GPA) } \\
\hline$>4.5-5$ & $9(13.4)$ & $197(27.7)$ & \multirow{4}{*}{$0.029^{*}$} \\
\hline$>3.75-4.5$ & $26(38.8)$ & $225(33.7)$ & \\
\hline $2.00-3.75$ & $32(47.8)$ & $246(37.4)$ & \\
\hline$<2.00$ & $0 \quad(0.0)$ & $9(1.2)$ & \\
\hline \multicolumn{4}{|l|}{ Marital status } \\
\hline Single & $60(89.6)$ & $614(90.7)$ & \multirow{3}{*}{0.594} \\
\hline Married & $7(10.4)$ & $56 \quad(8.3)$ & \\
\hline Divorced & $0 \quad(0.0)$ & $7(1.0)$ & \\
\hline
\end{tabular}


Table 2 - History and experience of donation among registered and unregistered students.

\begin{tabular}{|c|c|c|c|}
\hline Variable & On registry & Not on registry & $P$-value \\
\hline \multicolumn{4}{|c|}{ Donated marrow in the past } \\
\hline Yes & $6 \quad(9.0)$ & $6 \quad(0.8)$ & \multirow{2}{*}{$0.000^{*}$} \\
\hline No & $61(91.0)$ & $671(99.2)$ & \\
\hline \multicolumn{4}{|c|}{ Donated peripheral blood stem cells in the past } \\
\hline Yes & $12(18.0)$ & $10 \quad(1.5)$ & \multirow{2}{*}{$0.000^{*}$} \\
\hline No & $55(82.0)$ & $667(98.65)$ & \\
\hline \multicolumn{4}{|c|}{ Donated stem cells to a family member } \\
\hline Yes & $3(4.5)$ & $5 \quad(0.7)$ & \multirow{2}{*}{$0.005^{*}$} \\
\hline No & $64(95.5)$ & $672(99.3)$ & \\
\hline \multicolumn{4}{|c|}{ Donated stem cells to an unrelated recipient } \\
\hline Yes & $6(9.0)$ & $7 \quad(1.0)$ & \multirow{2}{*}{$0.000^{*}$} \\
\hline No & $61(91.0)$ & $670 \quad(99.0)$ & \\
\hline \multicolumn{4}{|c|}{ Donated blood or blood products } \\
\hline Yes & $24(36.0)$ & $128(19.0)$ & \multirow{2}{*}{$0.001^{*}$} \\
\hline No & $43(64.0)$ & $549(81.0)$ & \\
\hline \multicolumn{4}{|c|}{ Family history of blood cancer } \\
\hline Yes & $7(10.4)$ & $42 \quad(6.2)$ & \multirow{2}{*}{0.182} \\
\hline No & $60(89.6)$ & $635(93.8)$ & \\
\hline
\end{tabular}

Table 3 - Knowledge assessment of all students.

\begin{tabular}{|c|c|c|}
\hline Knowledge assessment & $\begin{array}{c}\text { Correct responses } \\
\mathrm{n}(\%)\end{array}$ & Average knowledge \\
\hline Individual's inability to donate blood makes the individual unable to donate a bone marrow & $183(24.6)$ & \multirow{3}{*}{$\begin{array}{c}\text { Average donor } \\
\text { eligibility knowledge } \\
37.4 \%\end{array}$} \\
\hline To be registered in the Saudi stem cell donor registry you need to provide a blood sample & $385(51.7)$ & \\
\hline Ethnicity and race are important factors that influence finding a matched donor for stem cells transplantation & $267(35.9)$ & \\
\hline Harvested bone marrow from donor's hip in the operation room is required for bone marrow transplantation & $108(14.5)$ & \multirow{3}{*}{$\begin{array}{l}\text { Average donation } \\
\text { process knowledge } \\
23.57 \%\end{array}$} \\
\hline In-patient hospitalization is required for stem cell donors during the donation process & $209(28.1)$ & \\
\hline Stem cells donors are vulnerable to common serious side effects of stem cells donation & $209(28.1)$ & \\
\hline
\end{tabular}

donating stem cells to a family member $(p=0.999)$ or to an unrelated recipient $(p=0.916)$ were no longer significantly associated with being a member of SSCDR.

Students knowledge regarding donor eligibility and donation process. Average knowledge about $\mathrm{DE}$ across all respondents was found to be $37.4 \%$ and DP was found to be $23.6 \%$ (Table 3). Registered students answered questions more correctly than non-registered students regarding the need for blood samples to be registered in SSCDR $(\mathrm{n}=53,79.1 \% ; p=0.00)$ and about serious side effects of stem cell donation $(\mathrm{n}=29$, $43.3 \% ; p=0.014)$. No significant difference was found between the correct answers of registered students and non-registered students about inability of someone to donate bone marrow if he or she cannot donate blood $(p=0.135)$, the effect of ethnicity and race on finding a matched donor for transplantation $(p=0.711)$, the need of harvesting marrow from the hip in order to donate stem cells in the operation room $(p=0.338)$, and required hospitalization during the donation process $(p=0.054)$ (Table 4).
Attitudes towards joining the SSCDR and donating hematopoietic stem cells (HSC). Registered students were found to have more positive attitudes about joining SSCDR and donating HSC. Registered students were more likely to respond; as they would join the registry if there were a drive applied in their area $(\mathrm{n}=65,97 \% p=0.000)$, more likely to donate stem cells to any patient they matched $(\mathrm{n}=58,86.6 \% p=0.000)$. The majority of registered students agreed that health professionals and students who have not registered to be a stem cell donor should go for registration $(\mathrm{n}=52$, [77.6\%], $p=0.000$ ). Responses to other questions about attitudes showed no significant difference between registered students and unregistered students (Table 5). Students were asked about their concerns regarding the long-term side effects and time commitment of stem cell donation, as well as about their feelings regarding any pain that may result from the donation process. Concern was greatest regarding long-term side effects (48.7\%), followed by time commitment (43.3\%), and pain resulting from the donation process (38.7\%). 
Registered students had fewer concerns regarding the pain of the procedure $(\mathrm{n}=33$ [49.3\%], $p=0.002)$ and the long-term side effects ( $\mathrm{n}=21$ [31.3\%], $p=0.044$ ) but we found no significant difference between the 2 groups regarding concerns about time commitment (Table 6).

Discussion. The SSCDR was established in April 2011 by King Abdullah International Medical Research Center, Riyadh, Saudi Arabia. The main objective of SSCDR is to create databases for the stem cells transplantation (SCT) for donors and recipients. Before SSCDR establishment it was estimated that one-third of adult patients and two-third of children had no opportunity to find a matching donor in their families. ${ }^{10}$ In our study, the percentage of registered students $(9 \%)$ was lower than that reported in other similar studies from different countries. The percentage of registered students was $43 \%$ in a study conducted at Mayo Medical School, Minnesota, USA and 32.7\% in Rhode Island study, and $16 \%$ at Lublin University, Lublin, Poland. ${ }^{1,13,14}$ This discrepancy can be attributed to variations in study size and population. We found that students between the ages of 23-25 and those studying in 4 th and 5 th years were the most represented

Table 4 - Knowledge comparison between registered and unregistered students $(\mathrm{N}=744)$.

\begin{tabular}{|c|c|c|c|}
\hline \multirow[t]{2}{*}{ Knowledge } & $\begin{array}{c}\text { Registered } \\
\text { medical } \\
\text { students } \\
(\mathrm{n}=67)\end{array}$ & $\begin{array}{c}\text { Non-registered } \\
\text { medical } \\
\text { students } \\
(\mathrm{n}=677)\end{array}$ & $P$-value \\
\hline & \multicolumn{2}{|c|}{ Correct responses $\mathbf{n}(\%)$} & \\
\hline \multicolumn{4}{|l|}{ Knowledge about the donor eligibility } \\
\hline $\begin{array}{l}\text { The inability to donate blood make the person unable to donate a bone marrow. } \\
\text { To be registered in the Saudi stem cell donor registry you need to provide a blood sample. } \\
\text { Ethnicity and race are important factors that influence finding a matched donor for transplantation. }\end{array}$ & $\begin{array}{l}23(34.3) \\
53(79.1) \\
21(31.3)\end{array}$ & $\begin{array}{l}160(23.6) \\
332(49.8) \\
246(36.3)\end{array}$ & $\begin{array}{l}0.135 \\
0.000^{*} \\
0.711\end{array}$ \\
\hline \multicolumn{4}{|l|}{ Knowledge about the donation process } \\
\hline $\begin{array}{l}\text { Harvested bone marrow from donor's hip in the operation room is required for bone marrow transplantation. } \\
\text { In-patient hospitalization is required for stem cell donors during the donation process. } \\
\text { Stem cells donors are vulnerable to common serious side effects of stem cells donation. }\end{array}$ & $\begin{array}{l}13(19.4) \\
24(35.8) \\
29(43.3)\end{array}$ & $\begin{array}{c}95(14) \\
185(27.3) \\
180(26.6)\end{array}$ & $\begin{array}{l}0.338 \\
0.054 \\
0.014^{*}\end{array}$ \\
\hline
\end{tabular}

Table 5 - Comparison of attitudes between registered and unregistered students ( $N=744)$.

\begin{tabular}{|c|c|c|c|c|c|c|c|}
\hline \multirow[t]{2}{*}{ Attitudes } & \multicolumn{3}{|c|}{ On registry $(n=67)$} & \multicolumn{3}{|c|}{ Not on registry $(n=677)$} & \multirow[t]{2}{*}{$P$-value } \\
\hline & Agree & Neutral & Disagreed & Agree & Neutral & Disagreed & \\
\hline \multicolumn{8}{|l|}{ Attitudes toward joining Saudi stem cell donor registry } \\
\hline I will join any donor registry drive applied in my area. & $65(97.0)$ & $2(3.0)$ & 0 & $407(60.1)$ & $208(30.7)$ & $62(9.2)$ & $0.000^{*}$ \\
\hline $\begin{array}{l}\text { During medical school days, If unrelated individual required stem } \\
\text { cells transplant I will donate my stem cells to him. }\end{array}$ & $52(77.6)$ & $13(19.4)$ & $2(3.0)$ & $430(63.5)$ & $186(27.5)$ & $61(9.0)$ & 0.051 \\
\hline $\begin{array}{l}\text { Health care professionals and medical students who haven't been on } \\
\text { stem cell donation registry should register. }\end{array}$ & $52(77.6)$ & $13(19.4)$ & $2(3.0)$ & $302(44.6)$ & $266(39.3)$ & $109(16.1)$ & $0.000^{*}$ \\
\hline \multicolumn{8}{|l|}{ Attitudes toward donating stem cells } \\
\hline I will donate my stem cells to any patient I match with. & $58(86.6)$ & $9(13.4)$ & 0 & $379(56.0)$ & $232(34.3)$ & $66(9.7)$ & $0.000^{*}$ \\
\hline $\begin{array}{l}\text { I will donate my stem cells to any family member needed bone } \\
\text { marrow transplant and matched with me. }\end{array}$ & $66(98.5)$ & $1 \quad(1.5)$ & 0 & $632(93.3)$ & $35 \quad(5.2)$ & $10(1.5)$ & 0.239 \\
\hline
\end{tabular}

Table 6 - Comparison concerns between registered and unregistered students (N=744).

\begin{tabular}{lccccccc}
\hline Concern & \multicolumn{3}{c}{ On registry $(\mathbf{n}=67)$} & \multicolumn{2}{c}{ Not on registry $(\mathbf{n}=677)$} & \multicolumn{2}{c}{$P$-value } \\
& Agree & Neutral & Disagree & Agree & Neutral & Disagree & \\
\hline Pain of the procedure & $20(29.8)$ & $14(20.9)$ & $33(49.3)$ & $268(39.6)$ & $214(31.6)$ & $195(28.8)$ & $0.002^{*}$ \\
Time commitment & $38(56.7)$ & $17(25.4)$ & $12(17.9)$ & $284(41.9)$ & $239(35.3)$ & $154(22.8)$ & 0.065 \\
Long term side effects & $26(38.8)$ & $20(29.9)$ & $21(31.3)$ & $336(49.6)$ & $213(31.5)$ & $128(18.9)$ & $0.044^{*}$ \\
\hline
\end{tabular}


on the registry. Fifth year students have the highest proportion of registration. In our study, students being on the registry was found to be associated with previous history of blood donation and prior experience with bone marrow donation or peripheral blood stem cells donation. These results are similar to those of the Mayo Medical School, Minnesota, USA; as they found that prior blood donation rates were higher among registered students. In contrary to our results, they found age and educational level to be non-significant. ${ }^{1}$

Our literature search revealed very few studies on the knowledge of SCT among medical students with which we could compare our data. Our study showed that most students had inadequate knowledge on HSCT. Previous studies conducted among medical students and doctors in Tabouk, KSA and among nursing students in Malaysia revealed results similar to our findings. ${ }^{15,16}$ However, the majority of subjects in those studies had knowledge ranging from inadequate $(93.5 \%)$ to moderate $(92 \%)$ regarding SCT. Insufficient awareness regarding SCT was present among nursing students at King Saud bin Abdul-Aziz University, Riyadh, KSA and that was prior to implementation of an educational program about SCT. ${ }^{17}$ Similar results have also been reported in Turkey. ${ }^{18}$ These findings are consistent with other studies conducted to assess knowledge about SCT among students from different colleges and populations. For example, one study conducted in India among engineering students found that none had adequate knowledge about SCT, only $30.9 \%$ had moderate knowledge, and the rest had inadequate knowledge. ${ }^{19}$ On the other hand, Adediran et $\mathrm{al}^{20}$ also found inadequate knowledge about SCT among sickle cell patients. In our study, the inadequate knowledge about HSCT can be linked to a lack of information about HSCT in the curriculum. Although they have been exposed to hematological topics in the immune, blood, and lymphatic (IBL) module taken during the pre-clinical phase and the internal medicine modules taken during the clinical years but HSCT topic was not thoroughly included in these modules. Similar issue was found by other researchers who attributed this issue to the advanced nature of the topic for a medical student audience and superficially inclusion of the topic. ${ }^{15}$ In another studies, the issue was linked to religious issues. ${ }^{21,22}$ However, it is unlikely that religious issues are a contributing factor in KSA; as the art of SCT is widely used for various diseases in the country. ${ }^{15}$ When examining knowledge differences between registered students in the SCCDR and those who were not, we found that the registered students had greater knowledge about the blood sample required for registration and provided correct answers about the concerns. Similar findings were shown by Narayanan et al. ${ }^{1}$ Higher knowledge among registered ones also found by other researchers. ${ }^{11,12}$ The limited number of students on the registry or who donated stem cells can be attributed to the lack of knowledge about stem cell donation eligibility and the donation process. The barriers to donation and misconceptions about SCT should be dispelled to increase both the number of registrants and donations. Educational efforts can help address this issue. ${ }^{13}$

One of the main purposes of our study was to measure the attitudes towards joining the SSCDR and HSC. We found that registered students had more positive attitudes toward these topics. Registered students were greatly motivated and had more positive attitudes when compared with unregistered students, had a greater desire to donate if there was a drive in their area (97\%). Furthermore, they requested unregistered students and health professionals to participate effectively in the donation registry (77.6\%). Also, the registered students expressed willingness to donate stem cells to any patient they might match $(86.6 \%)$. We found that our results yielded higher percentages when compared with the results of another study that included the same questions. In another study, 64\% of registered students were willing to join a drive in their area, 5\% wanted unregistered students and health professionals to participate in the donation registry, and $75 \%$ were willing to donate stem cells to an unrelated recipient. ${ }^{1}$ We found that medical students were most concerned about the long-term side effects of donating stem cells (48.7\%), followed by time commitment (43.3\%), then pain of donation (38.7\%). Moreover, we found that the registered students were less concerned when compared to non-registered ones. These findings differ from those of Mayo Medical School, Minnesota, USA; as they found that the major concern among their studied subjects was "pain related to donation" (56\%), followed by time commitment $(52 \%)$ and long-term side effects (39\%). However, they also found that concerns were lower among registered students, which is similar to our findings. In another study in Rhode Island, similar concerns were found to affect students' participation in stem cell donation. ${ }^{13}$ Student attitudes and registration rates can be improved through education, including lectures that focus on SCT, evidence-based intervention, and by stressing on the fact that thousands on the waiting list for stem cell donation die each year because no suitable donor can be found. ${ }^{13,18}$

Study limitations. The present study involved only medical students. No doubt inclusion of students 
from other colleges or universities might yield more valuable results. Also, this study is not representative of the general population. However, medical students' knowledge on HSCT is considered of paramount importance as they can easily explore their knowledge to their community.

In conclusion, the majority of students lack the knowledge on HSCT. However, the students who registered in SSCDR had better knowledge and attitudes towards HSCT than the unregistered ones. Long-term side effects of HSCT were the most common concern of the participants. However, time commitment was the major concern of the registered students. The results of this study provide significant implications for health authorities in Jazan, KSA.

However, further studies are required to explore the knowledge of HSCT among the community. Finally, we recommend the addition of HSCT topic to medical schools' curriculum asides implementation of community health education programs in our region.

Acknowledgment. The authors gratefully acknowledge SCRIBENDI (www.scribendi.com) for their English language editing.

\section{References}

1. Narayanan P, Wolanskyj A, Ehlers SL, Litzow MR, Patnaik MS, Hogan WJ, et al. Medical students' knowledge, familiarity, and attitudes towards hematopoietic stem cell donation: stem cell donation behaviors. Biol Blood Marrow Transplant 2016; 22: 1710-1716.

2. Copelan EA. Hematopoietic stem-cell transplantation. NEnglJ Med 2006; 354: 1813-1826.

3. Anasetti C, Logan BR, Lee SJ, Waller EK, Weisdorf DJ, Wingard $\mathrm{JR}$, et al. Peripheral-blood stem cells versus bone marrow from unrelated donors. N Engl J Med 2012; 367: 1487-1496.

4. Loberiza FR Jr, Serna DS, Horowitz MM, Rizzo JD. Transplant center characteristics and clinical outcomes after hematopoietic stem cell transplantation: what do we know? Bone Marrow Transplant 2003; 31: 417-421.

5. Kollman C, Howe CW, Anasetti C, Antin JH, Davies SM, Filipovich $\mathrm{AH}$, et al. Donor characteristics as risk factors in recipients after transplantation of bone marrow from unrelated donors: the effect of donor age. Blood 2001; 98: 2043-2051.

6. La Nasa G, Vacca A, Littera R, Piras E, Orru S, Greco M, et al. What unrelated hematopoietic stem cell transplantation in thalassemia taught us about transplant immunogenetics. Mediterr J Hematol Infect Dis 2016; 8: e2016048.

7. Balcı YI, Tavil B, Tan CS, Ozgur TT, Bulum B, Cetin M, et al. Increased availability of family donors for hematopoietic stem cell transplantation in a population with increased incidence of consanguinity. Clin Transplant 2011; 25: 475-480.

8. Zaini RG. Sickle-cell anemia and consanguinity among the Saudi Arabian population. Arch Med 2016; 8: 2-4.

9. El-Mouzan MI, Al-Salloum AA, Al-Herbish AS, Qurachi MM, Al-Omar AA. Regional variations in the prevalence of consanguinity in Saudi Arabia. Saudi Med J 2007; 28: 1881-1884.
10. El-Hazmi MA, Al-Swailem AR, Warsy AS, Al-Swailem AM, Sulaimani R, Al-Meshari AA. Consanguinity among the Saudi Arabian population. J Med Genet 1995; 32: 623-626.

11. Alsultan A, Jastaniah W, Al Afghani S, Al Bagshi MH, Nasserullah Z, Al-Suliman AM, et al. Demands and challenges for patients with sickle-cell disease requiring hematopoietic stem cell transplantation in Saudi Arabia. Pediatr Transplant 2016; 20: 831-835.

12. Bedi KK, Hakeem AR, Dave R, Lewington A, Sanfey H, Ahmad N. Survey of the knowledge, perception, and attitude of medical students at the University of Leeds toward organ donation and transplantation. Transplant Proc 2015; 47: 247-260.

13. Vasconcellos A, Nunes A, Feller E. Knowledge, attitudes, and behaviors regarding the bone marrow registry among college and medical students in Rhode Island. Med Health R I 2011; 94: 302-305.

14. Sikora A, Wiorkowski K, Szara P, Drabko K. Knowledge and attitude of Lublin universities students' toward the opportunity of becoming unrelated bone marrow donor. Folia Med Cracov 2014; 54: 27-33.

15. Almashori MM, Alaradi BI, Altoairqi L, Ali F, Altemani MF, Elbeltagy M, et al. Knowledge, attitude and practice of doctors and medical students towards stem cell Use in the management of diabetes mellitus. Egypt J Hosp Med 2018; 71: 3308-3313.

16. Lye JL, Soon LK, Wan Ahmad WA, Tan SC. Knowledge and attitude about stem cells and their application in medicine among nursing students in universiti Sains Malaysia, Malaysia. Malays J Med Sci 2015; 22: 23-31.

17. Azzazy HM, Mohamed HF. Effect of educational intervention on knowledge and attitude of nursing students regarding stem cells therapy. J Nurs Heal Sci 2016; 5: 75-80.

18. Kaya Z, Gültekin KE, Demirtaş OK, Karadeniz D, Çalapkulu Y, Tap Ö. Effects of targeted education for first-year university students on knowledge and attitudes about stem cell transplantation and donation. Exp Clin Transplant 2015; 13: 76-81.

19. Sruthy V, Hem M. Peripheral blood stem cell donation awareness among college students. Int J Sci Technol Manag 2015; 04. Available from: www.ijstm.com.

20. Adediran A, Kagu MB, Wakama T, Babadoko AA, Damulak DO, Ocheni S, et al. Awareness, knowledge, and acceptance of haematopoietic stem cell transplantation for sickle cell anaemia in Nigeria. Bone Marrow Res 2016; 2016: 7062630.

21. Farley MA. Handbook of stem cells (second edition). Stem cell research - religious considerations. 2013 [Cited 2019 August 24]. Available from: https://www.sciencedirect.com/science/ article/pii/B9780123859426000810?via\%3Dihub

22. Aksoy S. Making regulations and drawing up legislation in Islamic countries under conditions of uncertainty, with special reference to embryonic stem cell research. J Med Ethics 2005; 31: 399-403. 